\title{
Using a Macroalgal Functional Form Approach to Assess the Level of Disturbance of Seagrass Meadows in Bahía of Nuevitas, Cuba (2000-2002)
}

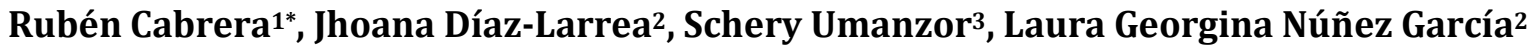 \\ ${ }^{1}$ Gabinete de Arqueología, Oficina del Historiador de la Ciudad, Habana Vieja, Cuba \\ ${ }^{2}$ Departamento de Hidrobiología, Universidad Autónoma Metropolitana-Iztapalapa, Mexico City, Mexico \\ ${ }^{3}$ Department of Ecology \& Evolutionary Biology, University of Connecticut, Stamford, CT, USA \\ Email: *cabrera algas@gmail.com, jhoanadiazl@gmail.com, gior@xanum.uam.mx, schery.umanzor@uconn.edu
}

How to cite this paper: Cabrera, R., Díaz-Larrea, J., Umanzor, S. and García, L.G.N. (2019) Using a Macroalgal Functional Form Approach to Assess the Level of Disturbance of Seagrass Meadows in Bahía of Nuevitas, Cuba (2000-2002). American Journal of Plant Sciences, 10, 2020-2033.

https://doi.org/10.4236/ajps.2019.1011142

Received: October 10, 2019

Accepted: November 18, 2019

Published: November 21, 2019

Copyright $\odot 2019$ by author(s) and Scientific Research Publishing Inc. This work is licensed under the Creative Commons Attribution International License (CC BY 4.0).

http://creativecommons.org/licenses/by/4.0/

\section{(c) (i) Open Access}

\begin{abstract}
A study on the spatial and seasonal variations of the associate macroalgae and epiphytes of Thalassia testudinum was carried out in Bahía de Nuevitas. Sixty-two species were identified: 3 Cyanophyta, 25 Chlorophyta, 8 Phaeophyceae, 23 Rhodophyta and 3 Magnoliophyta, with two new records for Cuba and 43 for the area. The differences in the specific composition of the macroalgae communities are determined by a space component related to the type of affectation in each area. The morpho-functional groups of macroalgae in the station with more nutrient influence were mainly foliaceous and filamentous. In the stations far from the city, the predominant morpho-types were the leathery and articulate calcareous indicators of lower nitrification levels. The abundance and diversity of macroalgae in the site affected by fisheries were lower due to the damage by bottom trawls. Seasonal variations were found in the relative abundance of the species, not in the diversity, which makes evident seasonal changes in the structure of the seaweeds, where some species replace others in the community.
\end{abstract}

\section{Keywords}

Cuba, Epiphytes, Thalassia, Morpho-Functional Groups, Seaweeds

\section{Introduction}

Seagrasses form highly productive ecosystems comparable to the most produc- 
tive biomes on Earth [1]. Seagrass ecosystems operate based on food chains underpinned by detritivores and herbivores, where seagrass, as well as their accompanying epiphytes and associated macroalgae, is consumed [2]. Seagrass systems have been recognized as an important resource with its functions listed by [2] [3] [4] [5]. Similar to other marine ecosystems, seagrass meadows have diminished their coverage in part driven by warming sea surface temperatures but also by the direct effect of human intervention [6]. The most obvious anthropogenic-driven impacts on seagrasses occur in coastal areas adjacent to human settlements, where physical disturbance, organic enrichment, and overfishing activities result in the greatest negative impacts [7].

Seagrasses constitute one of the largest biotopes in Cuba, with Thalassia testudinum dominating meadows $(1-4 \mathrm{~m})$ on the island shelf. The total area of the Earth covered by seagrass beds is poor known, but recent estimates are between 300,000 and $600,000 \mathrm{~km}^{2}$ [8] [9]. Thalassia is associated with a great diversity of organisms, among which macroalgae stand out. Macroalgae are more efficient than seagrasses in their ability to uptake nutrients, vulnerable to mechanical damage, and their abundance and species composition can be used to determine the degree of disturbance in the ecosystem [10] [11], refer to different morpho-functional groups in macroalgae and describe their relationship to the level of environmental disturbance. A sufficient understanding of these categories allows simplifying the interpretation of patterns in environmental conditions, whether biotic or abiotic, by including a high number of species [12]. In fact, macroalgae have been used as indicators of environmental quality, particularly when linked to pollution [13] [14].

Bahía of Nuevitas, Cuba, in one of the sites on the island where seagrass meadws are disturbed directly by wastewaters and dragnet fishing, increasing stress on marine biodiversity of the area [7]. To date, there are no records of any studies using the morpho-functional approach described by [10] as a tool for evaluating the degree of disturbance. There are several records of a survey conducted by [15] [16] [17] [18], identifying macroalgae and phanerogams, as well as their biomass. As such, in this study we report on the analysis of spatial and temporal variations of the specific composition and abundance of the accompanying macroalgae and epiphytes of Thalassia testudinum forming beds in three areas of Bahía of Nuevitas. These sites differ in the degree of anthropogenic influence, which will help to evaluate the sensitivity of using the morpho-functional approach. It will also contribute to expanding the knowledge of the marine flora in the Caribbean.

\section{Materials and Methods}

Assessments were conducted in three different stations within Thalassia testudinum beds growing in Nuevitas Bay. Station 1 was located in Cayo Puto $\left(21^{\circ} 31^{\prime} 06^{\prime \prime} \mathrm{N} ; 077^{\circ} 16^{\prime} 15^{\prime \prime} \mathrm{W}\right)$. This station is continuously affected by wastewater discharges from an industrial and urban origin that mix with its muddy substrate full of debris derived from red mangrove trees. Station 2 in Playa Bagá 
$\left(21^{\circ} 28^{\prime} 43^{\prime \prime} \mathrm{N} ; 077^{\circ} 15^{\prime} 84^{\prime \prime} \mathrm{W}\right)$ is frequented used for dragnet fishing, while station 3 in Júcaro which was used as reference site $\left(21^{\circ} 32^{\prime} 89^{\prime \prime} \mathrm{N} ; 077^{\circ} 08^{\prime} 0^{\prime \prime} \mathrm{W}\right)$, is a more pristine location deprived of direct influence of contaminants or fishing. This site has a muddy-sandy substrate with a variety of shells and rocks available for colonization (Figure 1).

Macroalgal samples were collected from each station in February, August, and October 2001, and January and April 2002. A10 × $25 \mathrm{~cm}$ quadrat was used to designate 12 sampling units (UM) per station from which all associated macroalgae were identified and quantified. Additionally, 15 shoots of Thalassia per station were collected randomly to evaluate epiphytic macroalgae. After collection, a value of relative abundance was assigned to each species of macroalgae identified [19]. These values were used to calculate Shannon-Weaver diversity index [20] following a Jackknife resampling method. To evaluate the appropriateness of our sample size (i.e. minimum area), we created cumulative curves of the number of species vs. UM [21] [22].

Many studies had been done by other authors, which was to our advantage because classification was an important part of this paper [23]-[28]. Moreover,

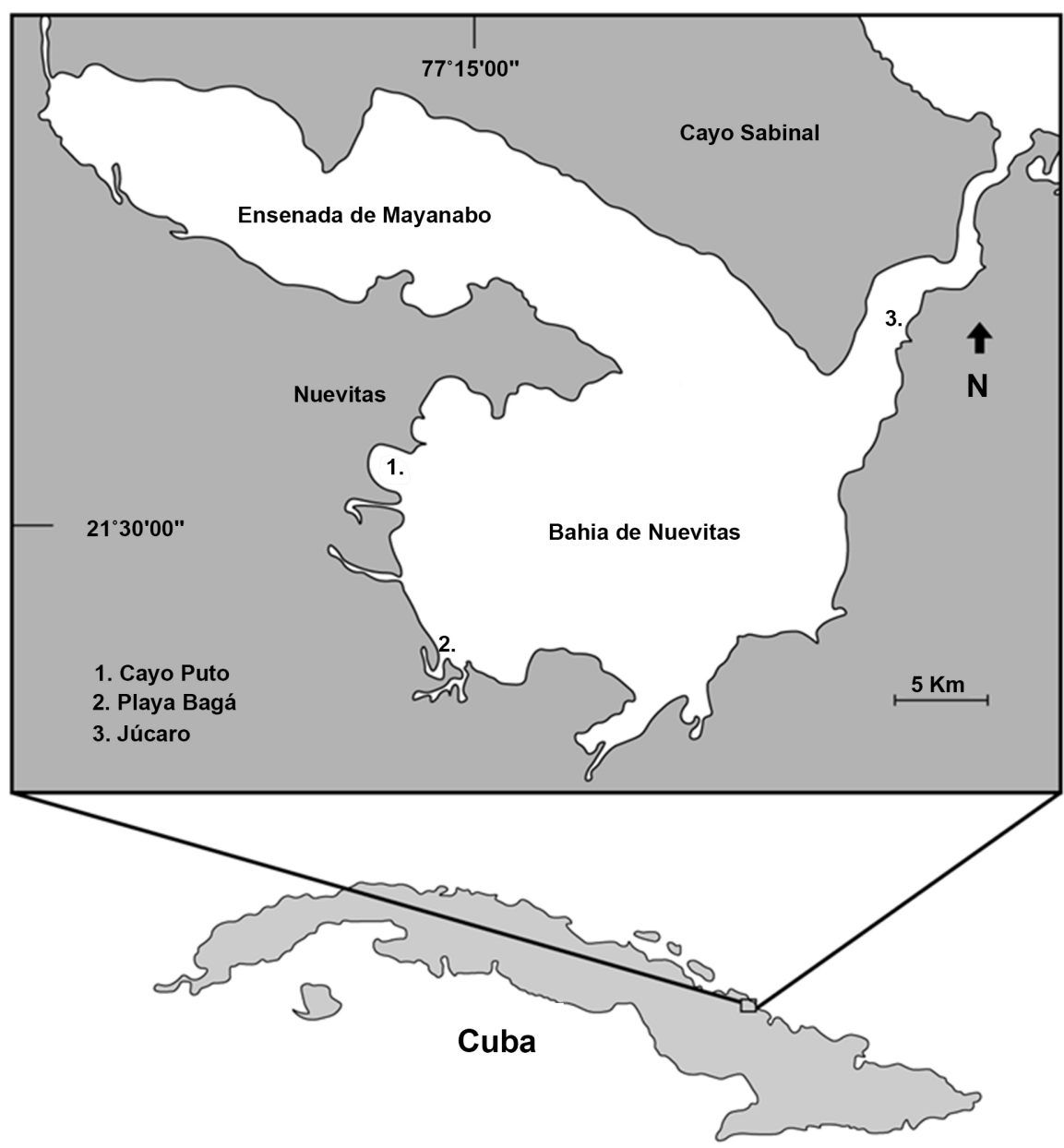

Figure 1. Geographical location of Nuevitas Bay and sampling sites. Legend: 1 = Cayo Puto, 2 = Playa Bagá 3 = Júcaro. 
all macroalgal species were organized according to their morpho-functional grouping [9], season, and month when they were collected. Epiphytes were not grouped because of the majority of species corresponded to early stages of succession and Thalassia showing a high rate of leaves renewal, thus increasing the challenge of interpreting temporal patterns.

A fixed-effect two-factor ANOVA was used to analyze all data. Transformations $\left(\mathrm{x}^{0.25}\right)$ were performed as required to fulfill the assumptions of normality and homogeneity of variances per factor and level [29]. For all data, where significant differences were found ( $\alpha$ 0.05), post-Hoc, Student-Newman-Keuls (SNK), comparisons were conducted. A classification analysis (Dissimilarity Coefficient Bray-Curtis) was performed to group the combinations of macroalgal species per month across the sampling stations with the inverse matrix. Moreover, the percentage dissimilarity coefficient [21] was used as an affinity index with the unprocessed abundance data. This included only species that accumulated $95 \%$ of the total number of relative abundance [30].

A spatial representation of the morpho-functional per across months and sampling stations grouping was obtained using a Non-Metric Multidimensional Scaling (NMMDS) approach computed with the same affinity index. These analyses were performed on the MVSP [31] and STATISTICA v. 7.0 [32] programs. The index of constancy and nodal fidelity were used to assess the correspondence between the grouping results by season and by species [21].

\section{Results and Discussion}

The curves of the number of species vs. UM showed that. The cumulative curves show an asymptotic tendency that stabilizes at 12 and $9 \mathrm{UMs}$, for the epiphytic and associated macroalgae, respectively. This confirms that the sample size used was optimal in defining the structure of the macroalgal communities (Figure 2). [33], argues that the best dimension for UM should be the smallest possible and that random sampling ensures greater accuracy in the determination of the mean and variance.

Our results show 59 epiphytic or associated macroalgae species. These included 3 Cyanophyta, 25 Chlorophyta, eight Phaeophyceae, 23 Rhodophyta and 3 Magnoliophyta (Table 1). Moreover, the inverse dissimilarity coefficient (by species) allowed defining three distinct morpho-functional groups (Figure 3, Table 1). All of them present in different proportions at the three sampling stations and represented with high fidelity according to the nodal analysis (Table 2). The model of morpho-functional groups was developed to synthesize the variations in the morphology of the thallus as a response to different ecological conditions [11]. Analyzing the distribution of macroalgae within this context allows grouping species with greater fidelity per station, thus enabling to distinguish the dominance of specific morphotypes as a function of the environmental conditions per site.

The analysis of relative abundance shows significant differences between stations $\left(\mathrm{F} \times 21.83, p \times 0.001^{\star *}\right)$ and months $\left(\mathrm{F} \times 2.55, p<0.038^{\star}\right)$, while the 


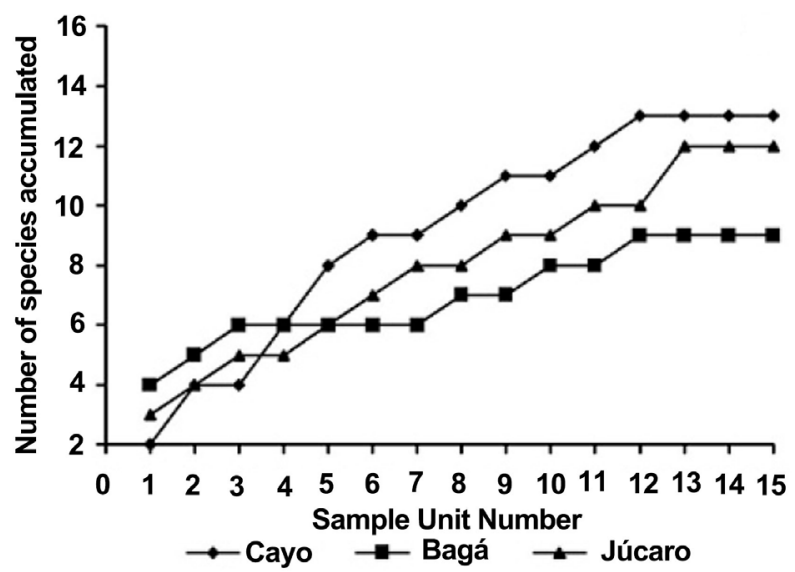

(a)

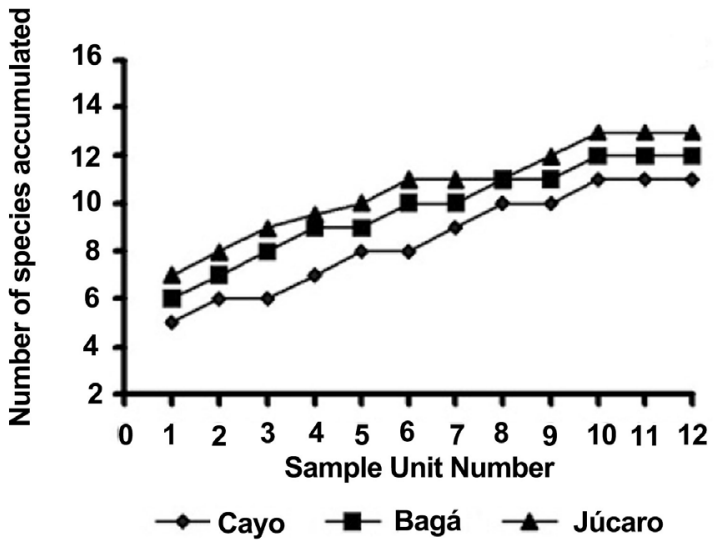

(b)

Figure 2. Number of species accumulated by sample unit in the three stations studied. (a) Epiphytic macroalgae and (b) associated macroalgae.

Shannon-Weaver diversity index only shows differences between stations $(\mathrm{F} \times$ 33.50, $p<0.001^{* *}$ ) (Figure 4). Cayo Puto station shows the highest abundance and diversity of macroalgae (Figure 4(a), Figure 4(b)) presumably because the site is sheltered from strong oceanic bulk water flow. These results coincide with observations by [34], who found that the number of species increases in areas with lower mechanical disturbance and rich in nutrients compared to areas with higher disturbance and low nutrient availability. Other authors, however, consider that low diversity is typical of areas with heavy nutrient loads [35]. Contrary to Cayo Puto, Playa Bagá station shows the lowest abundance and diversity of macroalgae (Figure 4(a), Figure 4(b)). This could be associated with the mechanical damage caused by trawls and dragnets increasing physical stress in the meadow [7]. The spatial variations were best explained by the differences nutrients and substratum between sampling sites [17].

On the other hand, Júcaro station shows the greatest number of associated species, while the epiphyte component was lower than in Cayo Puto. Moreover, October showed the lowest values of abundance across sites (Figure 4(c)). 
Table 1. Macroalgae and cyanophytes species present as epiphytes or associated with Thalassia testudinum. Abbreviations were assigned as a reference to highlight those species that accumulated $95 \%$ of abundance across sites. Groups are based on the inverse dissimilarity coefficient by species). ${ }^{*}$ indicates new records for Cuba according [40], ** indicates new records for the region.

\begin{tabular}{|c|c|c|}
\hline$T A X A$ & ABREVIATIONS & GROUP \\
\hline \multicolumn{3}{|l|}{ RHODOPHYTA } \\
\hline Hydrolithon farinosum (Lamouroux) Penrose et Chamberlain ${ }^{* *}$ & HYDFAR & II \\
\hline Pneophyllum fragile Kützing** & PNEFRA & II \\
\hline Jania adhaerens Lamouroux ${ }^{* *}$ & JANADH & II \\
\hline Hypnea musciformis (Wulfen) Lamouroux & HYPMUS & III \\
\hline \multicolumn{3}{|l|}{ Gracilaria blodgettii Harvey** } \\
\hline Gracilaria caudata J. Agardh ${ }^{\star *}$ & GRACAU & III \\
\hline Gracilaria damaecornis J. Agardh ${ }^{* *}$ & GRADAM & III \\
\hline Gracilariopsis lemaneiformis (Bory)Daw. Acleto et Foldvik ${ }^{* *}$ & GRALEM & I \\
\hline Champia parvula (C. Agardh) Harvey & CHAPAR & III \\
\hline Lomentaria baileyana (Harvey) Farlow ${ }^{\star *}$ & LOMBAI & II \\
\hline Aglaothamnion herveyi (Home) Aponte Ballantine et Norris** & AGLHER & III \\
\hline Centroceras clavulatum (C. Agardh) Montagne ${ }^{* *}$ & CENCLA & III \\
\hline Ceramium cimbricum Petersen ${ }^{\star *}$ & CERCIM & III \\
\hline Ceramium flaccidum (Kützing) Ardisone ${ }^{* *}$ & CERFLA & II \\
\hline Spyridia filamentosa (Wulfen)Harvey & SPIFIL & III \\
\hline Wrangelia bicuspidata $\mathrm{B} \phi$ rgesen ${ }^{* *}$ & WARBIC & II \\
\hline \multicolumn{3}{|l|}{ Dasyabaillouviana (Gmelin) Montagne $e^{\star *}$} \\
\hline Acanthophora spicifera (Vahl) Børgesen ${ }^{* *}$ & ACASPI & II \\
\hline \multicolumn{3}{|l|}{ Digenea simplex (Wulfen) C. Agardh ${ }^{* *}$} \\
\hline Herposiphonia pecten-veneris (Harvey) Falkenberg ${ }^{\star *}$ & HERPEC & II \\
\hline Yuzurua poiteaui var. gemmifera (Harvey) M. J. Wynne ${ }^{\star *}$ & YUZPOI & I \\
\hline \multicolumn{3}{|l|}{ Laurencia obtusa (Hudson) Lamouroux ${ }^{* *}$} \\
\hline Polysiphonia havanensis Montagne ${ }^{\star \star}$ & & \\
\hline
\end{tabular}

\begin{tabular}{|c|c|c|}
\hline \multicolumn{3}{|c|}{ Phaeophyceae } \\
\hline Ectocarpus divergens Kornmann ${ }^{* *}$ & ECTDIV & III \\
\hline Feldmannia indica (Sonder) Womersley et Bailey ${ }^{\star *}$ & FELIND & III \\
\hline Sphacelaria tribuloides Menghini ${ }^{\star *}$ & SPHTRI & III \\
\hline Dictyota bartareysiana Lamouroux ${ }^{\star *}$ & DICBAR & III \\
\hline Dictyota caribaea Hörnig et Schnetter** & DICCAR & III \\
\hline Dictyota pulchella Hörnig et Schnetter** & DICPUL & III \\
\hline Padina perindusiata Thivy in Taylor** & PADPER & III \\
\hline Sargassum cymosum C. Agardh ${ }^{\star *}$ & SARCYM & III \\
\hline
\end{tabular}


Continued

\begin{tabular}{|c|c|c|}
\hline \multicolumn{3}{|l|}{ CHLOROPHYTA } \\
\hline Ulva flexuosa Wulfen ${ }^{* *}$ & ULVFLE & III \\
\hline Ulva prolifera Müller** & ULVPRO & III \\
\hline Bryopsis pennata Lamouroux ${ }^{* *}$ & BRYPUL & III \\
\hline Bryopsis plumosa (Hudson) C. Agardh ${ }^{* *}$ & BRYPEN & III \\
\hline Caulerpa ashmeadii Harvey & CAUASH & II \\
\hline \multicolumn{3}{|l|}{ Caulerpa cupressoides var. lycopodium Weber Van-Bosse ${ }^{\star}$} \\
\hline \multicolumn{3}{|l|}{ Caulerpa mexicana Sonder ex Kützing } \\
\hline Caulerpa prolifera (Forsskal) Lamouroux & CAUPRO & II \\
\hline \multicolumn{3}{|l|}{ Caulerpa racemosa (Forsskal) J.Agardh } \\
\hline Caulerpa sertularioides (Gmelin) Howe & CAUSER & II \\
\hline \multicolumn{3}{|l|}{ Caulerpa sertularioides $\mathrm{f}$. longiseta (Bory) Svedelius ${ }^{\star *}$} \\
\hline Caulerpaverticillata J. Agardh & CAUVER & I \\
\hline Avrainvillea asarifolia Børgesen ${ }^{\star *}$ & AVRASA & II \\
\hline \multicolumn{3}{|l|}{ Avrainvilleaasarifolia f. olivacea Littler et Littler** } \\
\hline Halimeda incrassata (Ellis) Lamouroux & HALINC & II \\
\hline Halimeda monile (Ellis et Solander) Lamouroux ${ }^{* *}$ & HALMON & II \\
\hline \multicolumn{3}{|l|}{ Halimeda monile f. cylindrica (Børgesen) Collins et Hervey ${ }^{* *}$} \\
\hline Halimedaopuntia (Linnaeus) Lamouroux & HALOPU & II \\
\hline Halimeda opuntia f. triloba (Decaisne) J. Agardh ${ }^{* \star}$ & HALTRI & II \\
\hline Halimeda simulans Howe $\mathrm{e}^{\star *}$ & HALSIM & I \\
\hline Penicillus capitatus Lamarck & PENCAP & II \\
\hline Udotea cyathiformis f. sublitoralis (Taylor) Littler et Littler** & UDOSUB & II \\
\hline Udotea flabellum (Ellis et Solander) Howe $e^{* *}$ & UDOFLA & II \\
\hline Udotea goreaui Littler et Littler * & & \\
\hline Udotea luna Littler et Littler** & & \\
\hline
\end{tabular}

\begin{tabular}{ccc}
\hline \multicolumn{2}{c}{ CYANOPHYTA } & \\
\hline Aphanothece microscopica (Bréb) & APHMIC & III \\
Lyngbya majuscula (Dillwyn) Harvey & LYNMAJ & III \\
Oscillatoria sp. & OSCILLA & I \\
\hline
\end{tabular}

MAGNOLIOPHYTA: Thalassia testudinum Banks ex König; Syringodium filiforme Kützing; Halodule wrigthii Ascherson.

Temporal variations were only evident in terms of the relative abundance but not diversity, showing seasonal changes in the qualitative structure of macroalgal communities, where some species replace others across seasons. Similar results observed by [36].

The NMMDS constructed with percentage dissimilarity coefficient shows a clear separation of macroalgal communities as a function of sampling stations 
Table 2. Consistency values and nodal fidelity for each group of species (I-III) within each group of stations (A-C). A = Cayo Puto; $\mathrm{B}=$ Playa Bagá; $\mathrm{C}=$ Júcaro.

\begin{tabular}{ccccc}
\hline & & Consistency & \\
\hline & & A & B & C \\
\hline \multirow{3}{*}{ Species } & I & 0.32 & 2.37 & 0.20 \\
& II & 2.83 & 0.65 & 0.38 \\
& III & 0.13 & 0.29 & 2.72 \\
\hline \multirow{3}{*}{ Species } & & Fidelity & & C \\
& & A & B & 0.32 \\
& I & 0.32 & 2.37 & 0.38 \\
& II & 2.20 & 0.51 & 2.68 \\
\hline
\end{tabular}

Dissimilarity Coefficient

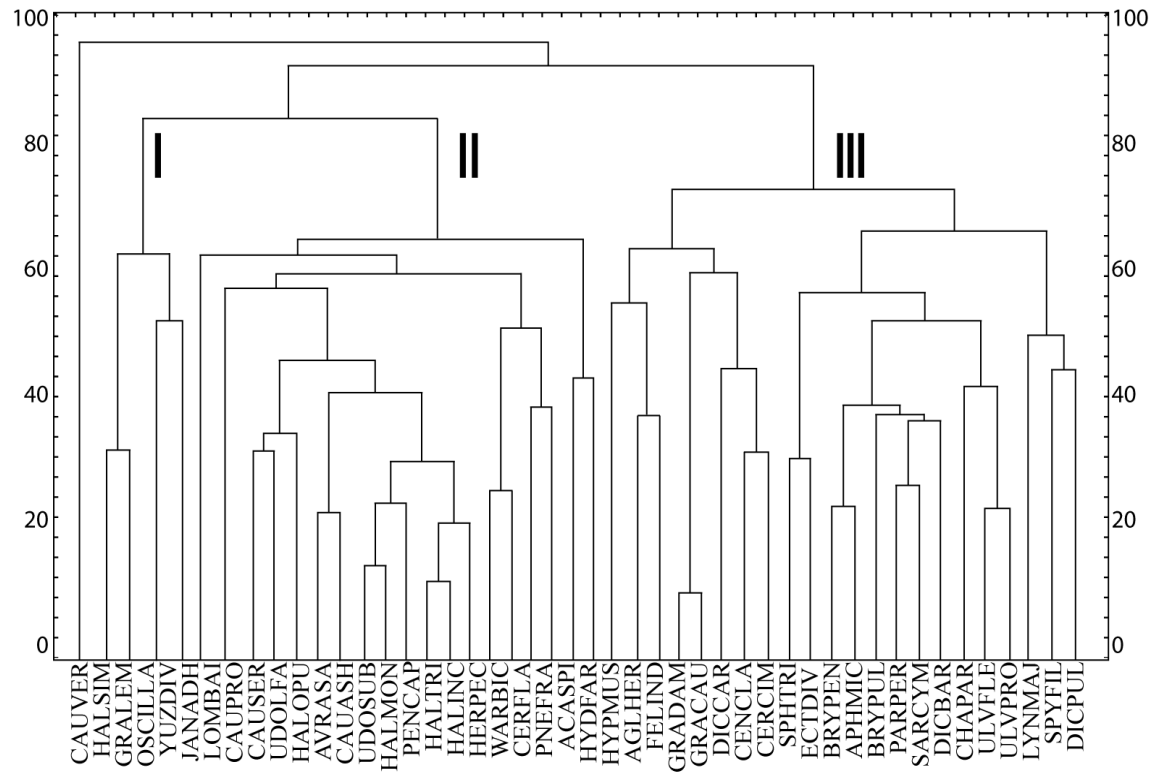

Figure 3. Analysis of numerical classification of species, using the percentage dissimilarity coefficient as an affinity index.

(Figure 5), with Cayo Puto distancing from Playa Bagá and Júcaro the most. The grouping generated with the NMMDS coincides with that of the three morpho-functional forms (Figure 3) shown by the macroalgae species identified. The morpho-functional group I shows the greater fidelity in Playa Bagá where the number of species is low. Here, macroalgae show a discrete development and absence of conspicuous algal communities. Here trawling and dragnet fishing seem to contribute to maintaining early successional stages. When fishing activity ceased in April, this group declined considerably and was replaced by calcified-articulated and leathery macroalgae, which showed their highest abundance in August (Figure 6). 
(a)

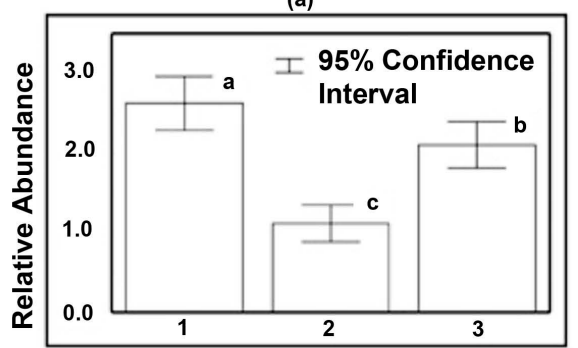

(b)

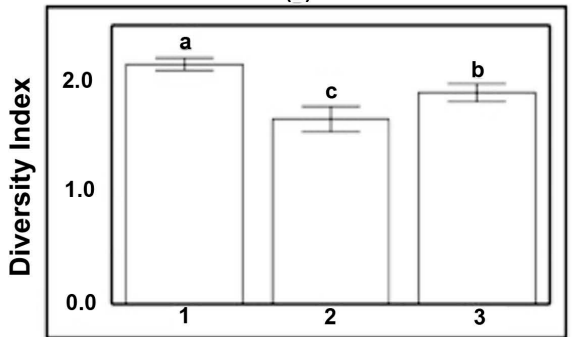

(c)

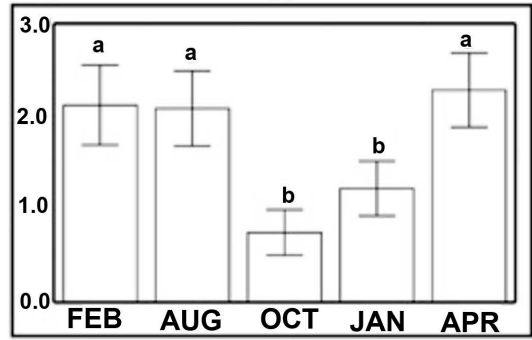

Figure 4. Mean values and confidence interval of relative abundance and Shannon diversity. Different letters indicate significant differences according to the SNK test. (a) Relative abundance per station; (b) Relative abundance for Months; (c) Diversity index. The stations are indicated in the figure: 1 = Cayo Puto; 2 = Playa Bagá; 3 = Júcaro.

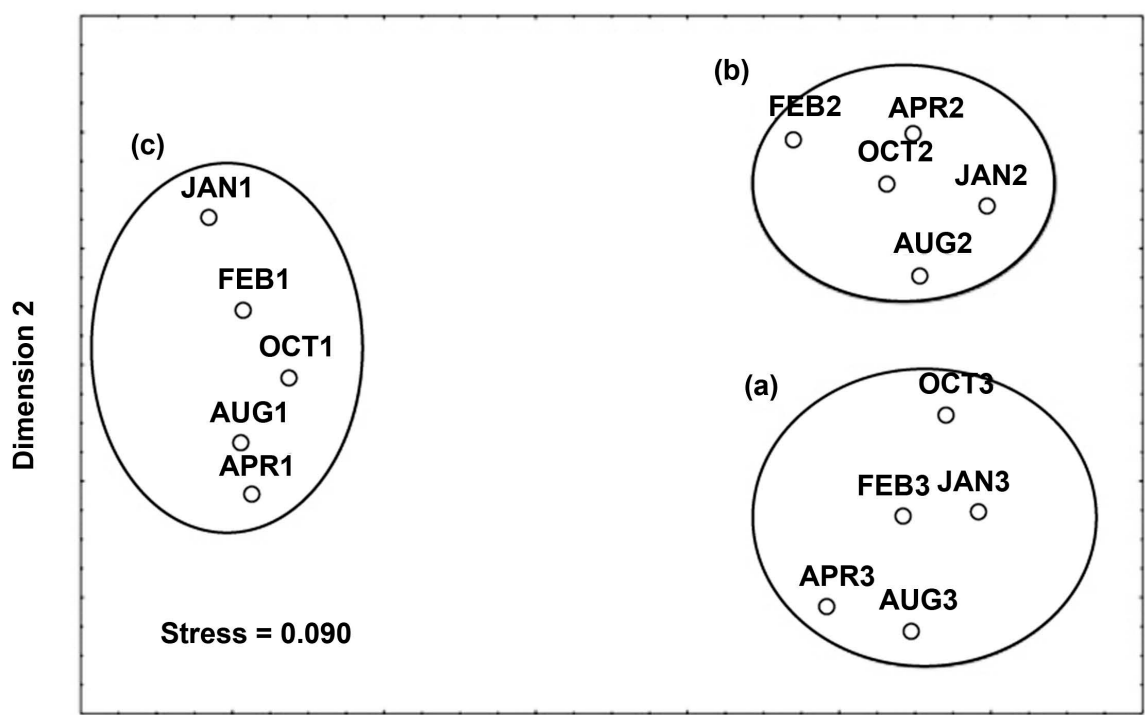

Dimension 1

Figure 5. Spatial distribution of macroalgal species using a Non-Metric Multidimensional Scale with the percentage dissimilarity coefficient as an affinity index. Legend: (a) Cayo Puto, (b) Playa Bagá, C = Júcaro. Months: JAN = January, FEB = February, ABR, = April, $\mathrm{AGO}=$ August, and OCT $=$ October. Number in the circles: $1=$ Cayo Puto, 2 = Playa Bagá, 3 = Júcaro.

Macroalgae species within group II (i.e. leathery and articulated-calcified species) dominated in Júcaro. Most species within this group are typical of sites with limited physical disturbance. Species are characterized by showing slow-growth and thalli with abundant calcium carbonate. These species are 


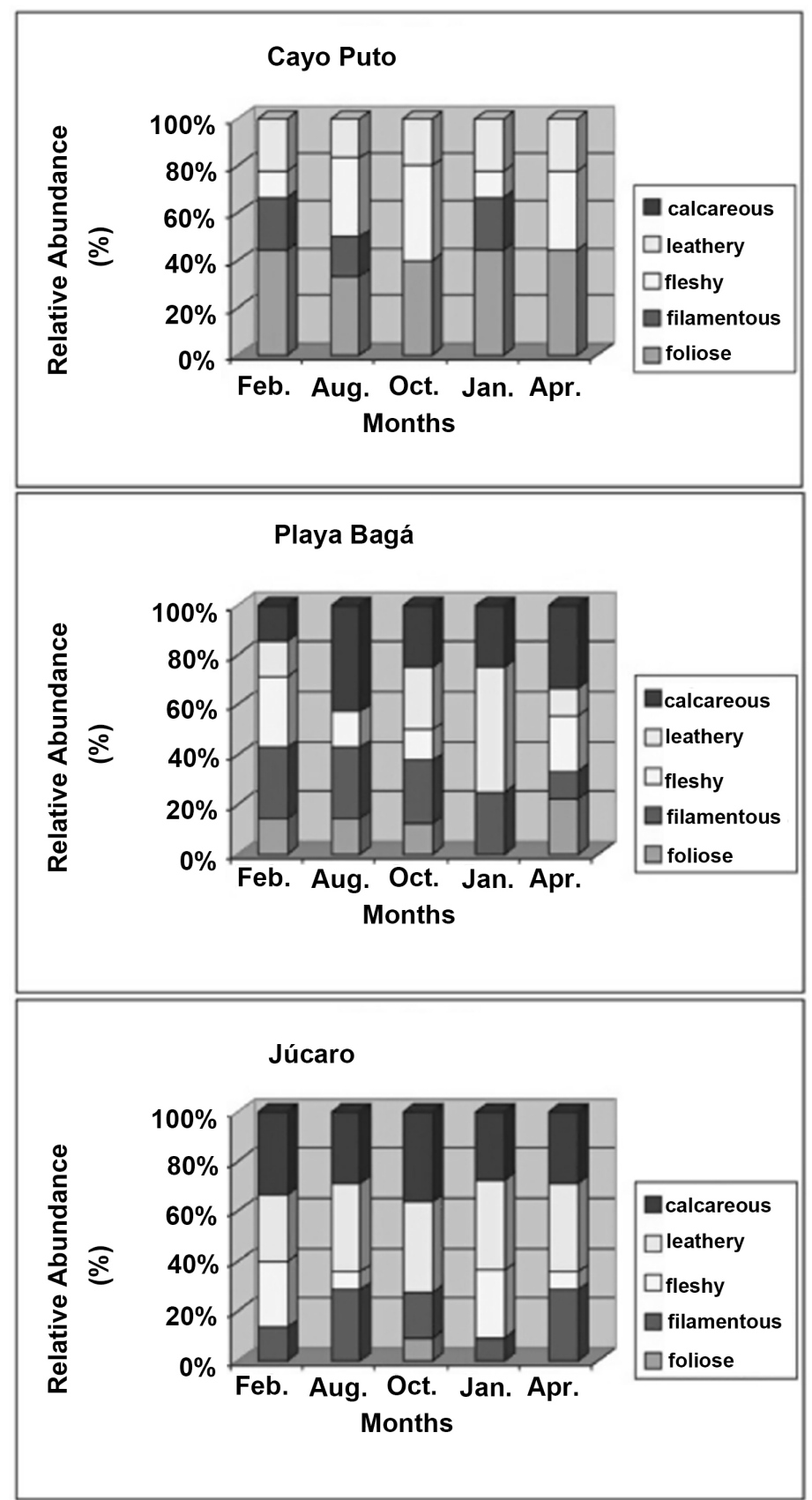

Figure 6. Distribution of morpho-functional macroalgae groups associated with Thalassia testudinum by station and months.

typical of areas with low nutrient levels [37] [38]. The dominant specimens in Playa Bagá are within the order Bryopsidales (i.e. Halimeda, Udotea, and Penicillus). However, other coralinaceae, as well as the genus Caulerpa were also present. Caulerpa, which is generally not calcified, showed calcification at site. A trait that is common at sites showing stable and constant environmental conditions [27]. Lastly, species within group III shows mostly associated with Cayo Puto. The majority of species identified were foliose and filamentous epiphytes. No articulated limestone species were observed, which typical of mature environments 
(Figure 6). These results coincide with macroalgal morphologies frequent in areas subjected to organic enrichment [35]. Similarly, [38] found that the genera Spyridia, Ulva, Bryopsis, and Dictyota predominate in nutrient-enriched areas, such as Cayo Puto. Furthermore, Gracilaria caudata and G. damaecornis, which were also present at site, are also typical of areas with high nutrient loads [38] [39]. These results coincide with who compared zones with different levels of degradation.

Our results highlight the option of using morpho-functional grouping as a tool to analyze the overall macroalgae community structure across sites [11] [12] [36]. Results also confirm that the spatial variation of the macroalgal community across seagrass meadows at Nuevitas is much more noticeable and decisive than the temporal variation. These variations appear to be determined, at least to some extent, by the degree of anthropogenic impact (i.e. nutrient enrichment and physical disturbance be trawling and dragnet fishing) but also due to abiotic factors such as water movement, as described in [7]. In Cuba, [41] recognized that seagrass ecosystems are very important for sustaining fisheries, along with coral reefs and mangroves.

\section{Conclusions}

Sixty-two species were recorded at three sites within Bahía of Nuevitas in Cuba. These include 3 Cyanophyta, 25 Chlorophyta, 8 Phaeophyceae, 23 Rhodophyta, and 3 Magnoliophyta.

Sites showing the highest physical disturbance have the lowest relative abundance and diversity of macroalgal, while a greater abundance and diversity was observed in stations with higher levels of nutrients.

Differences in the specific composition of macroalgal communities are determined by a spatial rather than a temporal component.

Macroalgae within the foliose and filamentous groups dominated in the station with the highest levels of nutrients. On the other hand, articulated-calcified and leathery macroalgae dominated stations with lower nutrients loads and physical disturbance.

\section{Acknowledgements}

The authors thank Dr. Michel J. Wynne for reading the manuscript and adding valuable suggestions for improvement. Thank you, Jose Rodrigo Umanzor for assistance in editing all graphs. Very thank José Rodrigo Umanzor for his assistance in editing all figures.

\section{Conflicts of Interest}

The authors declare no conflicts of interest regarding the publication of this paper.

\section{References}

[1] Duarte, C.M. and Chiscano, C.L. (1999) Seagrass Biomass and Production: A Reassessment. Aquatic Botany, 65, 159-174. 
https://doi.org/10.1016/S0304-3770(99)00038-8

[2] Hemminga, M.A. and Duarte, C.M. (2000) Seagrass Ecology. Cambridge University Press, Cambridge, 298 p. https://doi.org/10.1017/CBO9780511525551

[3] Zieman, J.C. (1975) Seasonal Variation of Turtle Grass, Thalassia testudinum König, with Reference to Temperature and Salinity Effects. Aquatic Botany, 2, 107-123. https://doi.org/10.1016/0304-3770(75)90016-9

[4] Zieman, J.C. (1986) Gradients in Caribbean Coastal Seagrass Ecosystems. Unesco Reports in Marine Science, 41, 25-29.

[5] Alcolado, P.M. (1990) Ecological Aspects of the Macrolaguna of the Gulf of Batabanó, with Special Reference to the Bentos. In: Alcolado, P.M., Ed., The Bentos of the Macrolaguna of the Gulf of Batabanó, Academia, La Habana, 129-157.

[6] Richard, K.F., Unsworth, L.J., McKenzie, C.J., Collier, L.C., Cullen-Unsworth, H., Duarte, C.M., Eklöf, J.S., Jarvis, J.C., Jones, B.L. and Nordlund, L.M. (2018) Global Challenges for the Conservation of Seagrass. Ambio: A Journal of the Human Environment, 48, 801-815. https://doi.org/10.1007/s13280-018-1115-y

[7] Martínez-Daranas, B., Cabrera, R. and Pina, F. (2009) Spatial and Temporal Variability of Thalassia testudinum in Nuevitas Bay, Cuba. Revista Ciencias Marinas y Costeras, 1, 9-27. https://doi.org/10.15359/revmar.1.1

[8] Duarte, C.M., Middelburg, J.J. and Caraco, N. (2005) Major Role of Marine Vegetation on the Oceanic Carbon Cycle. Biogeosciences, 2, 1-8.

https://doi.org/10.5194/bg-2-1-2005

[9] Fourqurean, J.W., Duarte, C.M., Kennedy, H., Marba, N., Holmer, M.A., Mateo, E.T., Apostolaki, G.A., Kendrick, D., Krause-Jensen, K.J. and McGlatheryand Serrano, O. (2012) Seagrass Ecosystems as a Globally Significant Carbon Stock. Nature Geoscience, 5, 505-509. https://doi.org/10.1038/ngeo1477

[10] Wood, S. (1995) Seagrass Tells Water Quality Story. Fathom, 7, 3.

[11] Littler, M.M. and Littler, D.S. (1980) The Evolution of the Thallus and Survival Strategies in Benthic Macroalgae: Field and Laboratory Tests of a Functional Form Model. The American Naturalist, 116, 25-44. https://doi.org/10.1086/283610

[12] Littler, M.M., Littler, D.S. and Taylor, P.R. (1983) Evolutionary Strategies in a Tropical Barrier Reef System: Functional-Form Groups of Marine Macroalgae. Journal of Phycology, 19, 229-237. https://doi.org/10.1111/j.0022-3646.1983.00229.x

[13] Cormaci, M. and Furnari, G. (1999) Changes of the Benthic Algal Flora of the Tremiti Islands (Southern Adriatic) Italy. Hidrobiologia, 398/399, 75-79. https://doi.org/10.1023/A:1017052332207

[14] Hauxvell, J., Cebrián, J., Furlong, J. and Valiela, I. (2001) Macroalgal Canopies Contribute to Eelgrass (Zostera marina) Declinein Temperature Estuarine Ecosystems. Ecology, 82, 1007-1022. https://doi.org/10.1890/0012-9658(2001)082[1007:MCCTEZ]2.0.CO;2

[15] Martínez-Daranas, B., Jiménez, C. and Alcolado, P.M. (1996) Prospección del Macrofitobentos de los fondos blandos del Archipiélago Sabana-Camagüey, Cuba. Avicennia, 4/5, 77-88.

[16] Cabrera, R., Moreira, A. and Suárez, A.M. (2004) Variación en la composición y estructura de las asociaciones algales en la Bahía de Nuevitas, costa NE de Cuba. Revista Investigaciones Marinas, 25, 133-142.

[17] Cabrera, R., Moreira, A. and Primelles, J. (2006) Distribución de la biomasa de macroalgas en la Bahía de Nuevitas, Cuba. Revista Investigaciones Marinas, 27, 19-29.

[18] Martínez-Daranas, B., Cano-Mallo, M., Perdomo, M.E., Clero-Alonso, L., Díaz-Larrea, 
J., Guimaraes, M., Zúñiga-Rios, D., Alcolado, P.M., Duarte, C.M. and Siret, S. (2007) Estado de los pastos marinos. In: Alcolado, P.M., García, E.E. and Arellano-Acosta, M., Eds., Ecosistema Sabana-Camagüey: Estado actual, avances y desafíos en la protección y uso sostenible de la biodiversidad, Editorial Academia, La Habana, 51-56.

[19] Suárez, A.M., Aguilar, C. and González-Sansón, G. (1989) Comparación de dos métodos para la cuantificación del fitobentos. Revista Investigaciones Marinas, 10, 21-26.

[20] Margalef, R. (1982) Ecología. Ed. Omega, Barcelona, 951 p.

[21] Boesch, D.F. (1977) Application of Numerical Classification in Ecological Investigations of Water Pollution. Virginia Institute of Marine Science, Special Scientific Report, Vol. 77, ix + 113 p.

[22] Gonzáles-Sansón, G., Aguilar, C., Angulo, J. and Gándara, C. (1997) Spatial and Seasonal Variation of the Ichthyofauna in a Coastal Coral Reef in the Northwestern Region of Cuba. Revista Investigaciones Marinas, 18, 249-259.

[23] Taylor, W.R. (1960) Marine Algae of the Eastern Tropical and Subtropical Coasts of the Americas. The University of Michigan Press, Ann Arbor, 870 p.

[24] Joly, A.B. (1967) Generos de alghas marinhas do costa atlántica latino-americana. Editora da Sao Paulo, Sao Paulo, 461 p.

[25] Cordeiro-Marino, M. (1978) Rodoficeas bentónicas marinhas do estado de Santa Catarina. Rickia, 7, 1-243.

[26] Littler, D.S. and Littler, M.M. (1990) Systematics of Udotea (Bryopsidales, Chlorophyta) in the Tropical Western Atlantic. Phycologia, 29, 206-252. https://doi.org/10.2216/i0031-8884-29-2-206.1

[27] Littler, D.S. and Littler, M.M. (1997) An Illustrated Marine Flora of the Pelican Cays, Belize. Bulletin of the Biological Society of Washington, 9, 125-132.

[28] Littler, D.S. and Littler, M.M. (2000) Caribbean Reef Plants. Offshore Graphics Inc., Washington DC, $542 \mathrm{p}$.

[29] Zar, J.H. (1996) Biostatistical Analysis. 3rd Edition, Prentice Hall Inc., Upper Saddle River, $659 \mathrm{p}$

[30] Clarke, K.R. and Warwick, R.M. (1994) Change in Marine Communities: An Approach to Statistical Analysis and Interpretation. Natural Environment Research Council, Swindon, 144 p.

[31] Kovach, W.L. (1990) Multivariate Statiscal Package (MVSP) Shareware. 2.0 User's Manual.

[32] StatSoft Inc. (1995) STATISTICA for Windows (Computer Program Manual). Tulsa.

[33] Elliot, J.M. (1977) Some Methods for the Statistical Analysis of Samples of Benthic Invertebrates. 2nd Edition, Freshwater Biological Publ. 25, Freshwater Biological Association, Ambleside, $160 \mathrm{p}$.

[34] Kendrick, G.A. and Burt, J.S. (1997) Seasonal Changes in Epiphytic Macro-Algae Assemblages between Offshore Exposed and Inshore Protected Posidonia sinuosa Cambridge et Kuo Seagrass Meadows, Western Australia. Botanica Marina, 40, 77-85. https://doi.org/10.1515/botm.1997.40.1-6.77

[35] Littler, M.M. and Murray, M. (1978) Influence of Domestic Water on Energetic Pathways in Rocky Intertidal Communities. Journal Applied Ecology, 15, 583-595. https://doi.org/10.2307/2402612

[36] Dailé, A., Guimaraes, M. and Ortiz, R. (2013) Variación espacio-temporal de grupos 
morfo-funcionales de macroalgas en pastos marinos al norte de Ciego de Ávila, Cuba. Revista Investigaciones Marinas, 33, 14-22.

[37] Borowitzka, M.A. and Lethbridge, R.C. (1989) Seagrass Epiphytes. In: Larkum, A.W.D., McComb, A.J. and Shepherd, S.A., Eds., Biology of Seagrasses, Elsevier, Amsterdam, 458-485.

[38] Lapointe, B.E., Tomasko, D.A. and Matzie, W.R. (1994) Eutrophication and Tropic State Classification of Seagrass Communities in the Florida Keys. Bulletin Marine Science, 54, 696-717.

[39] Arévalo, R., Pinedo, S. and Ballesteros, E. (2007) Changes in the Composition and Structure of Mediterranean Rocky-Shore Communities Following a Gradient of Nutrient Enrichment: Descriptive Study and Test of Proposed Methods to Assess Water Quality Regarding Macroalgae. Marine Pollution Bulletin, 55, 104-113. https://doi.org/10.1016/j.marpolbul.2006.08.023

[40] Cabrera, R., Suárez, A.M., Pina, F. and Martínez-Daranas, B. (2003) Addition to the Chlorophyceas of Cuba (Bryposidales, Udoteaceae). Revista Investigaciones Marinas, 24, 71-72.

[41] Martínez-Daranas, B. and Suárez, A.M. (2018) An Overview of Cuban Seagrasses. Bulletin of Marine Science, 94, 269-282. https://doi.org/10.5343/bms.2017.1014 